\title{
Afghanistan, Narcotics and the International Criminal Court: From Port of Spain to Kabul, via Rome.
}

\author{
James Windle \\ Lecturer in Criminology and Criminal Justice, School of Law and Social Science, University \\ of East London, London, United Kingdom
}

Address all correspondence to: James Windle at J.Windle@uel.ac.uk

\section{Introduction}

In 1989 Trinidad and Tobago approached the UN General Assembly to re-open discussion on the establishment of an international narcotics court. The proposal was borne of a frustration with the inability of less developed states to investigate and prosecute international drug traffickers and, a perceived lack of cooperation between national law enforcement and judicial agencies. ${ }^{1}$ The proposal provided the impetus to a process which resulted in the formation of the International Criminal Court (henceforth Court or ICC). After a decade of negotiations the Rome Statute of the ICC included the following crimes under the Courts jurisdiction: crimes against humanity, genocide, war crimes and crimes of aggression. Narcotic trafficking was excluded from the Statute. ${ }^{2}$ In 2009, Trinidad and Tobago again lobbied for the inclusion of narcotics trafficking under Articles 121 and 125 of the Rome Statute. ${ }^{3}$ Narcotics' trafficking was again excluded, due to a lack of support. ${ }^{4}$

\footnotetext{
${ }^{1}$ A. Schloenhardt, 2004, 'Transnational Organised Crime and the International Criminal Court: Towards Global Criminal Justice', Crime in Australia: International Connections, Australian Institute of Criminology Conference, Melbourne, 29-30 November 2004; see M. Roth, 2005, 'Comparative Overview of Policing, Courts and Corrections', in P. Reichel (eds.) Handbook of Transnational Criminal Justice (London: Sage).

${ }^{2}$ Rome Statute of the International Criminal Court, 1998, U.N. Doc. A/CONF.183/9.

${ }^{3}$ United Nations, 2009, Rome Statute of the International Criminal Court. Rome, 17 July 1998:

Trinidad and Tobago: Proposal of Amendments. C.N.737.2009.TREATIES-9.

${ }^{4}$ D. Barrett, 2009, 'Trinidad and Tobago and Belize propose the inclusion of the Crime of International Drug Trafficking in the Rome Statute of the International Criminal Court'. International
} 
Windle (2012) Afghanistan, Narcotics and the ICC. Pre-print copy.

This article investigates the potential impact of inclusion of narcotic trafficking under the jurisdiction of the Court. Analysis uses the single case study of Afghanistan: the world's largest source of illicit opiates. To establish a foundation section one will discuss the four main objections to the inclusion of narcotics trafficking presented during the primary negotiations for the ICC. The article then moves beyond legal arguments by assessing the potential effects of the inclusion of narcotic trafficking by applying concepts and evidence from the drug control, policing and crime prevention literature. The conclusion weighs up a number of arguments for and against the inclusion of narcotic trafficking in the Rome Statute of the ICC.

\section{Legal objections}

2.1 Objection one: The inclusion of narcotics crimes would trivialize the role of the court

The primary objection of the Preparatory Committee of the Rome Statute was that the inclusion of narcotics related crimes might trivialize the role of the Court. ${ }^{5}$ Crimes under ICC jurisdiction must 'shock the conscience of humanity' or present a threat to 'the peace, security and well-being of the world' ${ }^{6}$ The exclusion of narcotics trafficking from the jurisdiction of the 1998 Rome Statute suggests that the drafters felt that the offence was neither sufficiently shocking nor threatening. This opinion, however, conflicted with a statement, also in 1998, by the UN General Assembly that:

... drugs are a grave threat to the health and well-being of all mankind, the independence of States, democracy, the stability of nations, the structure of all societies, and the dignity and hope of millions of people and their

Centre on Human Rights and Drug Policy (Consulted 18 May 2011)

http://www.humanrightsanddrugs.org/?p=768

${ }^{5}$ M. McConville, 2000, 'A Global War on Drugs: Why the United States Should Support the Prosecution of Drug Traffickers in the International Criminal Court', American Criminal Law Review. Vol. 75, No. 4: 75-103.

${ }^{6}$ Rome Statute of the International Criminal Court, 1998, op. cit. 
Windle (2012) Afghanistan, Narcotics and the ICC. Pre-print copy.

families. $^{7}$

Opiate consumption can be detrimental to the 'well-being' of many of the world's 12 to 21 million illicit opiate consumers. ${ }^{8}$ According to the World Health Organization opiate dependence represents a 'global health problem which presents enormous economic, personal and public health consequences'. ${ }^{9}$ Heroin, the most commonly consumed illicit opiate, is generally considered one of the most harmful licit or illicit drugs to the individual consumer and their community. ${ }^{10}$

As a threat to global 'peace' and 'security', there are links between some drug trafficking organizations and some insurgent/terrorist groups, including the Taliban and Al Qaeda. ${ }^{11}$ Furthermore, related violence and corruption can present a barrier to democratic consolidation, economic development and the rule of law. ${ }^{12}$ With regard to 'shocking the conscience of the world', maybe, as Hilary Charlsworth argues, international law should concentrate on issues which effect peoples everyday lives rather than disproportionately

\footnotetext{
${ }^{7}$ United Nations General Assembly, 1998, Political Declaration on Global Drug Control. S-20/2: preamble. Italics added.

${ }^{8}$ United Nations Office of Drugs and Crime, World Drug Report (New York, UNODC, 2011).

${ }^{9}$ World Health Organisation, 2009, Guidelines for the Phychosocially Assisted Pharmacology

Treatment of Opiate Dependence: 6. (Consulted 15 October 2009).

www.who.int/substance_abuse/.../opioid_dependence_guidelines.pdf

${ }^{10}$ L. Degenhardt, C. Day, S. Gilmour and W. Hall, 2006, 'The "lessons" of the Australian "heroin shortage"', Substance Abuse Treatment, Prevention, and Policy, Vol.1, No. 11; R. McCoun and P. Reuter, Drug War Heresies: Learning from Other Vices, Times, and Places (Cambridge: Cambridge University Press, 2001); D. Nutt, 2009, 'Estimating Drug Harms: A Risky Business', Eve Saville Lecture, Kings College Centre for Crime and Justice Studies. (Consulted 18 January 2010). http://www.crimeandjustice.org/opus1714/Estimating_drug_harms.pdf

${ }^{11}$ V. Felbab-Brown, Shooting Up: Counterinsurgency and the War on Drugs (Washington: Brookings Institute, 2010); See E. Björnehed, 2004, 'Narco-Terrorism: The Merger of the War on Drugs and the War on Terror', Global Crime. Vol. 6, No. 3/4: 305-324.

${ }^{12}$ A. Atkins, 'The Drugs Trade as a Development Issue: Proposals for an EU Response', Trocaire Development Review (Dublin: Trocaire, 1996); F.E. Thoumi, 1987, 'Some Implications of the Growth of the Underground Economy in Colombia', Journal of Interamerican Studies and World Affairs, Vol. 29, No. 2: 35-53; J. Windle, 2011, 'Ominous Parallels and Optimistic Differences: Opium in China and Afghanistan', Crime, Law and History, Vol 1, No. 2: 141-164.
} 
Windle (2012) Afghanistan, Narcotics and the ICC. Pre-print copy.

focusing on crises. ${ }^{13}$

\subsection{Objection two: Narcotics related crimes are better dealt with bilaterally or regionally}

Some states, including Syria and Sweden, argued that narcotics crimes were best dealt with bilaterally or regionally. ${ }^{14}$ These argument centred upon the concern that the investigation of drug trafficking is a lengthy, expensive and complicated process, involving long-term planning and extensive intelligence gathering (possible including infiltration into the target group and the provision of immunity to informants). In short, the nature of narcotic trafficking makes it better suited to national investigations. ${ }^{15}$

The bilateral nature of narcotics control, however, represents a major obstacle to the arrest and prosecution of major traffickers. ${ }^{16}$ Disputes can arise when multiple states claim jurisdiction over an offence or suspect, while insufficient transnational cooperation can limit evidence collection. In terms of extradition to states more able to prosecute, the punishable act must be defined as a serious criminal offence in both the requesting and receiver states. States may, furthermore, be unwilling to extradite or prosecute for fear of igniting violent protests, potentially based upon nationalistic sentiments. ${ }^{17}$ In theory, the Court removes many of the nationalistic barriers to extradition whilst providing a platform for cooperation and a mechanism to pressure states into compliance. ${ }^{18}$

${ }^{13}$ H. Charlseworth, 2002, 'International Law: A Discipline of Crises', Modern Law Review, Vol. 65, No. 3: 377-392.

${ }^{14}$ United Nations, 1998, United Nations Diplomatic Conference of Plenipotentiaries on the Establishment of an International Criminal Court Rome, 15 June - 17 July 1998 (Consulted 9 July 2006). http://untreaty.un.org/cod/icc/rome/proceedings/E/Rome\%20Proceedings_v1_e.pdf; United Nations, 1996, Preparatory Committee on the Establishment of an International Criminal Court: Informal group on General principles of Criminal Law. A/AC.249/1

${ }^{15}$ M.H. Arsanjani, 1999, 'The Rome Statute of the International Criminal Court', The American Journal of International Law, Vol. 93, No. 1: 22-43.

${ }^{16}$ See concerns of Trinidad and Tobago: United Nations, 2009, op. cit.

${ }^{17}$ M. McConville, 2000, op. cit.; W.N. Gianaris, 1992, 'The New World Order and the Need for an International Criminal Court', Fordham International Law Journal, Vol. 16 No. 1: 88-117.

${ }^{18}$ G. Bottini, 2004, 'Universal Jurisdiction after the Creation of the International Criminal Court', International Law and Politics, Vol. 36: 503-560. 
Windle (2012) Afghanistan, Narcotics and the ICC. Pre-print copy.

\subsection{Objection three: The inclusion of narcotics related crimes would overwhelm the Court.}

The 1996 Preparatory Committee, for what became the Rome Statute, declared that drug trafficking was:

... of such a quantity as to flood the court; the court would not have the necessary resources to conduct the lengthy and complex investigations required to prosecute the crimes.... ${ }^{19}$

A high threshold would, however, be set. Much like the crimes presently included under the Courts jurisdiction, narcotics related crimes would be bounded by severity. Articles 17 and 53 of the Rome Statute provide the Court discretionary powers to render any case inadmissible if 'not of sufficient gravity to justify further action by the Court'. All cases must, additionally, be in the 'interests of justice'. ${ }^{20}$

Furthermore, in 2006 the Court's Office of the Prosecutor published its 'Prosecutorial Strategy'. This instructs the prosecution to 'focus its efforts on the most serious crimes and on those who bear the greatest responsibility for these crimes'. The document lends substance to the vague concept of gravity by mandating the prosecutor to assess 'the scale of the crimes; the nature of the crimes; the manner of commission of the crimes; and the impact of the crimes'. ${ }^{21}$ Trinidad and Tobago's 2009 proposal to include trafficking under the Courts jurisdiction, similarly, limited prosecution to those which 'pose a threat to the peace, order and security of a State or region'. ${ }^{22}$ Additionally, the annex of an early draft statute for an international criminal court affirmed that trafficking would need to possess an

\footnotetext{
${ }^{19}$ United Nations, 1996, Preparatory Committee on the Establishment of an International Criminal Court: Informal group on General principles of Criminal Law: paragraph 72.

${ }^{20}$ Rome Statute of the International Criminal Court, 1998, op. cit.

${ }^{21}$ Cited in W.A. Schabas, 2008, 'Prosecutorial Discretion v. Judicial Activism at the International Criminal Court', Journal of International Criminal Justice Vol. 6: 731-761, p.736, Italics added.

${ }^{22}$ United Nations, 2009, op. cit.
} 
Windle (2012) Afghanistan, Narcotics and the ICC. Pre-print copy.

international character. $^{23}$

Furthermore, the Court is bounded by the concept of complementarily: it will only take cases which national courts are unable or unwilling to prosecute. ${ }^{24}$ In this regard, the ICC may be of use as a catalyst by coercing or directing national courts to prosecute major traffickers. ${ }^{25}$

The threshold issue may be best illustrated by a brief viewing of the list of traffickers extradited from Afghanistan to America. America does not extradite drug mules carrying a couple of grams of heroin, nor would the Court. The last three major traffickers to be extradited by America have all been linked to the insurgency or managed the trafficking of large quantities of illicit drugs over a number of years. ${ }^{26}$ In short, the threshold for Court involvement would be set at those with the greatest responsibility for the illicit trade.

\subsection{Objection four: The definition of narcotics related crimes was too vague.}

James Crawford posited that narcotics related crimes lacked sufficient definition to be prosecutable under the Rome Statute. ${ }^{27}$ The three international narcotics control conventions are, however, quite clear in what they criminalize $\mathrm{e}^{28}$ and the majority of domestic narcotic laws are already replicated upon them..$^{29}$ Bounded by the severity threshold discussed above,

\footnotetext{
${ }^{23}$ N. Boister, 1998, 'The Exclusion of Treaty Crimes from the Jurisdiction of the Proposed International Criminal Court: Law, Pragmatism and Politics', Journal of Armed Conflict Law. Vol. 3, No. 1: 27-44

${ }^{24}$ International Criminal Court. (Consulted 23 May 2011) http://www.icccpi.int/Menus/ICC/About+the+Court/

${ }^{25}$ See G. Bottini, 2004, op. cit.

${ }^{26}$ See C.M. Blanchard, Afghanistan: Narcotics and U.S. Policy (Congressional Research Service, RL32686, 2009).

${ }^{27}$ J. Crawford, 1995, 'The ILC Adopts a Statute for an International Criminal Court', The American Journal of International Law, Vol. 89, No. 2: 404-326. Henry Kissinger similarly argued that crimes against humanity and genocide were undefined: K. Roth, 2001, 'The Case for Universal Jurisdiction', Foreign Affairs, September/October: 150-154.

${ }^{28}$ See United Nations Convention Against Illicit Traffic in Narcotic Drugs and Psychotropic Substances, 1988 (New York: UN, 1988): Article 3(1).

${ }^{29}$ N. Boister, 1998, op. cit.
} 
Windle (2012) Afghanistan, Narcotics and the ICC. Pre-print copy.

existing international legislation provides sufficient definitional parameters.

This section has shown how there are few strong legal objections against the inclusion of narcotic trafficking under the jurisdiction of the Rome Statute. An equally important question, yet to be asked by the literature, is whether prosecuting trafficking in the ICC would have a noticeable effect upon national governments? The remainder of this article will engage this question by applying concepts and evidence from the drug control, policing and crime prevention literature to contemporary Afghanistan.

\section{Context: The Afghan criminal justice system}

To facilitate analysis of the effects of the ICC upon Afghanistan a brief overview of the state of the Afghan criminal justice system shall be provided. Afghanistan has 'historically been characterized by a weak state in dynamic relations with a strong society', resulting a series of complex relationships between the state and multiple 'micro-societies' based upon cultural, tribal or linguistic lines. ${ }^{30}$ Kabul presently exerts fragile control over some of the national territory, while parallel centres of authority exist throughout much of Afghanistan: some southern and eastern areas are governed entirely by the Taliban or state control is limited by the insurgency. ${ }^{31}$ For example, most major illicit opium poppy growing districts are largely inaccessible to UN agencies and non-governmental organizations as they fall under the authority of insurgents and/or criminal networks. ${ }^{32}$

\footnotetext{
${ }^{30}$ A. Saikal, 'Afghanistan: Elite Fragmentation', in W. Danspeckgruber, ed., Petersberg Papers on Afghanistan and the Region: Liechtenstein Colloquium Report 4. (New Jersey: Liechtenstein Institute on Self-Determination, 2009), p. 95.

${ }^{31}$ See J.P. Caulkins, M.A.R. Kleiman, and J.D. Kulick, Drug Production and Trafficking, Counterdrug Policies, and Security and Governance in Afghanistan (Centre on International Cooperation. New York: New York University, 2010); C.C. Fair and and S.G. Jones, 2009, Securing Afghanistan: Getting on Track. United States Institute of Peace Working Paper. (Consulted 28 June 2010). http://www.usip.org/publications/securing-afghanistan-getting-track; T. Masadykov, A. Giustozzi and J.M. Page, Negotiating with the Taliban: Towards a Solution for the Afghan Conflict (London: Crisis States Research Centre, London School of Economics, 2010).

${ }^{32}$ United Nations of Drugs and Crime, Afghan Opium Survey 2010 (UNODC, 2011).
} 
Windle (2012) Afghanistan, Narcotics and the ICC. Pre-print copy.

Even in areas with a significant state presence, the Government 'has neither the capacity nor the legitimacy to mobilize capital or coercion' ${ }^{33}$ Most state institutions are corrupt, lacking in adequate resources and trained personnel, and generally ineffective. ${ }^{34}$ The weakness in governance and lack of state authority is most conspicuous in the criminal justice system; 80/90 percent of Afghans ${ }^{35}$ choose to use informal dispute resolution mechanisms, or even the Taliban, rather than the formal criminal justice system, which is under-resourced, undertrained and inefficient. ${ }^{36}$

Decades of violent conflict corroded an already weak criminal justice system, limiting not only the material resources but also the pool of professional and trained coercive, legal and support personnel from which criminal justice systems are founded. At the time of writing, the judicial process is slow and open to corruption, while many buildings are unfit for court. ${ }^{37}$

The Ministry of the Interior is responsible for Afghan drug control. Due to high-levels of corruption, abuse and criminal activity, ${ }^{38}$ it has been described as a 'locus of corruption',

${ }^{33}$ J. Goodhand, 2008, 'Corrupting or Consolidating the Peace? The Drugs Economy and Post-conflict Peacebuilding in Afghanistan', International Peacekeeping, Vol. 15, No. 3: 405-423, p. 415.

${ }^{34}$ A. Saikal, 2009, op. cit; J. Windle and G. Farrell, 'Afghanistan', in G. Newman and D. Chung (eds.), Crime and Punishment Around the World, (Santa Barbara: ABC-CLIO, 2010).

${ }^{35}$ ISISC (Istituto Superiore Internazionale di Scienze Criminali), 2007, An Assessment of Justice Sector and Rule of Law Reform in Afghanistan and the Need for a Comprehensive Plan. (Consulted November 2007) http://www.rolafghanistan.esteri.it/ConferenceRol/Menu/Ambasciata/Gli_uffici/ ${ }^{36}$ See A. Wardak, 2006, Jirga - A Traditional Mechanism for Conflict Resolution in Afghanistan. Institute for Afghan Studies. (Consulted 12 November 2008) http://www.institute-for-afghanstudies.org/; A. Wardak, 'The Rule of Law in Afghanistan: An Overview', in W. Danspeckgruber, ed., Petersberg Papers on Afghanistan and the Region: Liechtenstein Colloquium Report 4 (New Jersey: Liechtenstein Institute on Self-Determination, 2009); J. Windle and G. Farrell, 2010, op. cit. ${ }^{37}$ J. Windle and G. Farrell, 2010, op. cit.; J. Windle, 2011, op. cit.; see N. Grono, 2011, Rule of Law and the Justice System in Afghanistan: Report to the Foreign and Commonwealth Office. (Consulted 18 May 2011) http://www.crisisgroup.org

${ }^{38}$ J. Windle and G. Farrell, 2010, op. cit.; see D. Mukhopadhyay, 2009, 'Disguised Warlordism and Combatanthood in Balkh: The Persistence of Informal Power in the Formal Afghan State', Conflict, Security \& Development, Vol. 9, No. 4: 535-564. 
Windle (2012) Afghanistan, Narcotics and the ICC. Pre-print copy.

composed of 'disrespected and feared' police officers. ${ }^{39}$ The 'criminalization' of the Afghan National Police has been reported as a problem of epidemic proportions, including extortion and robbery by officers. ${ }^{40}$ Few major traffickers have been prosecuted ${ }^{41}$ and many of those which have been incarcerated have managed to bribe their way to freedom. ${ }^{42}$ According to the US State Department 'many central, provincial, and district level government officials are believed to directly profit from the drug trade', ${ }^{43}$ including police chiefs and judges. ${ }^{44}$ This said, there have been many improvements in the Afghan criminal justice system, ${ }^{45}$ including the development of the promising Criminal Justice Task Force. ${ }^{46}$

For many of the Afghan political elite the opium trade is rewarding. Many 'warlords', appointed to legitimate political/bureaucratic positions after 2001, had previously exerted authority over aspects of the opiate trade. ${ }^{47}$ While formal ties with overt criminal activity

${ }^{39}$ N. Grono, 2009, 'Policing in Conflict States - Lessons from Afghanistan', International Police
Commissioners' Conference, The Hague, 16 June 2009. (Consulted 18 May 2011): no page number. http://www.crisisgroup.org

${ }^{40} \mathrm{~J}$. Windle and G. Farrell, 2010, op. cit.

${ }^{41}$ C.C. Fair and S.G. Jones, 2009, op. cit.

${ }^{42}$ B.A. Rubin and J. Sherman, Counter-Narcotics to Stabilize Afghanistan: The False Promise of Crop Eradication (New York: Centre for International Cooperation, 2009).

${ }^{43}$ US State Department, International Narcotics Control Strategy Report (Washington: US State Department, 2011), p. 103; see V. Felbab-Brown, 2009. 'The Drug Economy in Afghanistan and Pakistan, and Military Conflict in the Region', in E. Ahrari, V. Felbab-Brown, L. Shelley and N. Hussain (eds.) Narco-Jihad: Drug trafficking and Security in Afghanistan and Pakistan (The National Bureau of Asian Research, 2009).

${ }^{44}$ C.C. Fair and S.G. Jones, 2009, op. cit.

${ }^{45}$ A. Wardak, 2011, 'State and Non-State Justice Systems in Afghanistan: The Need for Synergy', University of Pennsylvania Journal of International Law, Vol. 32, No. 5: 1305-1324.

${ }^{46}$ In 2010 the Task Force convicted 56 Afghan officials for illicit drug related offences: US State Department, 2011, op. cit.

${ }^{47}$ S. Baldauf and F. Bowers, 2005, 'Afghanistan Riddled with Drug Ties,' Christian Science Monitor, May 13 2005; L. Paoli, V.A. Greenfield, and P. Reuter, The World Heroin Market: Can Supply be Cut? (Oxford: Oxford University Press, 2009). 
Windle (2012) Afghanistan, Narcotics and the ICC. Pre-print copy.

were rejected in order to enter legitimate state institutions, several exploited their position by protecting 'former' contacts. ${ }^{48}$

Importantly, many informal (and formal) power-holders insulated themselves from the narcotics trade. Some local governors are believed to eradicate opium poppies in their sphere of influence to show foreign donors their prohibitionist credentials. The interventions are, however, often intended to reduce competition and divert attention from their own illicit activities. $^{49}$

A less iniquitous obstruction to the state (or political elite) from perceiving suppression as in their best interest may be that a sharp decline in production would be economically and politically damaging. ${ }^{50}$ Afghanistan is one of the least developed countries in the world. The Government have reported that 12 million individuals survive below the poverty line; the UN Development Programme in 2009 ranked Afghanistan the fourth poorest country in the world in terms of food security. ${ }^{51}$ In 2009 , opium was produced by 6 percent of the population, or roughly 1.5 million people. ${ }^{52}$ It was estimated that a third of the national population relied upon opiate generated revenue while a quarter of all economic activity was centred upon opium. ${ }^{53}$ Some politicians - echoing scholarly opinion - have expressed concern that the removal of the opium economy would strengthen the insurgency and alienate rural

\footnotetext{
${ }^{48}$ M. Shaw, 'Drug Trafficking and the Development of Organised Crime in Post-Taliban Afghanistan', in D. Buddenberg and W. Byrd, Afghanistan's Drug Industry: Structure, Functioning, Dynamics and Implications for Counter-Narcotics Policy (New York: World Bank and UNODC, 2006).

${ }^{49}$ Felbab-Brown, 2009. op. cit.

${ }^{50}$ J. Windle, 2011, op. cit.

${ }^{51}$ W. Danspeckgruber, 'Background and Summary', in W. Danspeckgruber, ed., Petersberg Papers on Afghanistan and the Region: Liechtenstein Colloquium Report 4 (New Jersey: Liechtenstein Institute on Self-Determination, 2009).

${ }^{52}$ United Nations of Drugs and Crime, 2011, op. cit.

${ }^{53}$ See W.A. Byrd, 'Responding to the Challenge of Afghanistan's Opium Economy: Developing Lessons and Policy Implications', in P. Keefer and N. Loayza, eds., Innocent Bystanders: Developing Countries and the War on Drugs (Washington: Palgrave MacMillan, 2010); B.A. Rubin and J.
} Sherman, 2009, op. cit. 
Windle (2012) Afghanistan, Narcotics and the ICC. Pre-print copy.

populations. ${ }^{54}$ While the trade represents a barrier to long-term economic growth and foreign investment, ${ }^{55}$ support is understandably low for a policy which could remove the income of a third of the population, destabilise the economy and ignite anti-government feelings. ${ }^{56}$ With the contextual foundation in place the remainder of this article shall discuss how the inclusion of narcotics trafficking under the Rome Statute might impact Afghanistan.

\section{Potential effects}

\subsection{Effects: Immunity}

A key aim of the Court is to limit immunity from prosecution. ${ }^{57}$ Immunity may result from intimidation, institutional ineffectiveness or, an unwillingness/inability to arrest or prosecute. ${ }^{58}$ As such, it is unsurprising that many Afghan traffickers enjoy immunity. High levels of corruption, violence, intimidation and lack of state authority in some areas facilitate immunity and, thus, trafficking. Additionally, the suppression of trafficking is understandably not a national priority for many of the political elite. President Karzai, for example, has often been unwilling to prosecute corrupt officials to avoid pushing allies towards supporting antigovernment forces. ${ }^{59}$ Yielding jurisdiction to the ICC would limit some of this self-interest ${ }^{60}$

\footnotetext{
${ }^{54}$ C.C. Fair and S.G. Jones, 2009, op. cit.; V. Felbab-Brown, 2009, op. cit.

${ }^{55}$ World Bank, Afghanistan - State Building, Sustaining Growth, and Reducing Poverty (Washington: World Bank, 2005).

${ }^{56}$ J. Windle, 2011, op. cit.; There are innovative proposals for Afghan farmers to grow opium for the licit pharmaceutical market. While this warrants further investigation, until the state has strengthened it is unlikely that such a programme would benefit the Afghan people nor represent the most efficient means of development. See J. Windle, 2011, 'Poppies for Medicine in Afghanistan: Historical
} Lessons from India and Turkey', Journal of Asian and African Studies. Vol. 46, No. 6: 663-677.

${ }^{57}$ R. Blattmann and K. Bowman, 2008, 'Achievements and Problems of the International Criminal Court: A View From Within', Journal of International Criminal Justice Vol. 6: 711-730, p. 722.

${ }^{58}$ See K. Roth, 2001, op. cit.; A. Schloenhardt, 2004, op. cit.

${ }^{59}$ C.C. Fair and S.G. Jones, 2009, op. cit.; The Afghan Government is not the first government to disregard the objectives of prohibition for the objectives of security. For multiple examples see: A. McCoy, The Politics of Heroin: CIA Complicity in the Global Drug Trade (Chicago: Lawrence Hill Books, 2003).

${ }^{60}$ G. Bottini, 2004, op. cit. 
Windle (2012) Afghanistan, Narcotics and the ICC. Pre-print copy.

and, may reduce the pressure exerted on the Government and judiciary by insulating them from making and executing precarious decisions.

While a functioning Court might reduce some of the intimidation and violence against the judiciary, the negotiations for ratification of the Rome Statute could spark a wave of protests and violence orchestrated by those threatened by the loss of immunity. For example, in 1980, Colombia ratified an extradition treaty with America. The Medellín and Cali cocaine trafficking networks perceived this as a threat and increased their procurement of political protection whilst waging a high-casualty campaign of violence against the state. ${ }^{61}$

As importantly is the potential for cooperative warlords/traffickers to break away from the state by aligning themselves with anti-Government forces. The fragility of Afghanistan means that the primary consideration of any intervention must be stability and state extension. The realities of Afghan state building may, therefore, demand the necessity of brokering deals with strategically important traffickers. If this is the case then the Court's prosecutors 'may not be the best judge of whether a prosecution' ${ }^{62}$ is in the national interest.

This said, a number of major traffickers have been arrested by American agents and extradited to America. ${ }^{63}$ While there are no available reports of protests against extradition in Afghanistan, similar cases in Columbia sparked nationalistic anger and provided political capital to anti-government forces. ${ }^{64}$ The Court could, therefore, provide 'a neutral international forum ${ }^{65}$ which may limit nationalistic (or anti-American) protestations.

The Court may additionally provide a remedy to Afghanistan's notoriously inefficient prison system. Suspects would be detained in a much more secure prison, close to the ICC in The

\footnotetext{
${ }^{61}$ See F.E. Thoumi, 'Competitive Advantages in the Production and Trafficking of Coca-Cocaine and Opium-Heroin in Afghanistan and the Andean Countries', in P. Keefer and N. Loayza, (eds.) Innocent Bystanders: Developing Countries and the War on Drugs (Washington: Palgrave MacMillan and World Bank, 2010).

${ }^{62}$ R. Wedgewood, 1991, 'The International Criminal Court: An American View', European Journal of International Law, Vol. 10: 93-107, p. 96.

${ }^{63}$ C.C. Fair and S.G. Jones, 2009, op. cit.

${ }^{64}$ See F.E. Thoumi, 2010, op. cit.

${ }^{65}$ W.N. Gianaris, 1992, op. cit, p. 90.
} 
Windle (2012) Afghanistan, Narcotics and the ICC. Pre-print copy.

Hague, until sentencing. After which they sit out their sentence in a secure prison chosen by the Court. The security situation in Afghanistan's leading prison - Pol-e-Charki - has been described by a UN official stationed in Afghanistan as 'shaky'. This is largely due to largescale corruption and insufficient resources. The official tellingly continued that 'Pol-e-Charki is a great prison compared to the other prisons in the country....Most are uninhabitable' ${ }^{66}$ Whilst renovation of the prison system is ongoing, it has been fraught with difficulties and continues to exhibit significant security weaknesses, ${ }^{67}$ including cases of convicted traffickers being freed after paying bribes ${ }^{68}$ and the escape of 500 prisoners from Kandahar prison in May 2011. ${ }^{69}$

In terms of law enforcement, if used effectively the Court would be able to collate evidence from a number of domestic and foreign jurisdictions, ${ }^{70}$ including Interpol. Allowing the prosecution to build a stronger case than it would by relying on evidence collected from just one or two jurisdictions. ${ }^{71}$

Much of the aforementioned positives are somewhat symbolic. They will communicate to the Afghan people that: the state is unwilling to tolerate traffickers, none are immune from the law, all are equal before the law and the state has the capabilities to arrest and prosecute powerful offenders. If communicated effectively this symbolism may go some way to improving the low-levels of trust the Afghan peoples have in the Afghan criminal justice system. Illustrating the ability to bring powerful offenders to justice would additionally

\footnotetext{
${ }^{66}$ L. Dobbs, 2006, 'A Pilot for Prison Reform'. UNAMA Update No. 12: 2-3, p. 2.

${ }^{67}$ G. Farrell, M. Alam and C. Plunet, Thematic Evaluation of the Technical Assistance Provided to Afghanistan by the United Nations Office of Drugs and Crime (Vienna: UNODC, 2008).

${ }^{68}$ C.C. Fair and S.G. Jones, 2009, op. cit.

${ }^{69}$ Economist, 2011, 'Break for the Hills,' Economist, 15 April, 2011.

${ }^{70}$ W.N. Gianaris, 1992, op. cit.

${ }^{71}$ While, in theory the ICC should improve cooperation, in reality a lack of cooperation has limited many of the investigations and execution of arrest warrants issued by the Court since its inauguration: R. Blattmann and K. Bowman, 2008, op. cit.; see N. Grono, 2008, The International Criminal Court: Success or Failure? (Consulted 19 July 2011) http://www.opendemocracy.net/article/theinternational-criminal-court-success-or-failure
} 
Windle (2012) Afghanistan, Narcotics and the ICC. Pre-print copy.

undermine one of the Taliban's main selling points: that it can provide quick, harsh and 'fair' justice. $^{72}$

The symbolism argument could, however, be reversed. While it may illustrate that the state is willing to enforce the law, it may conversely demonstrate the inherent weaknesses in the countries infant criminal justice system. The astute Afghan may read the involvement of the ICC for what it is: a response to the corruption, inefficiency and immunity inherent in a criminal justice system which protects the powerful.

\subsection{Effects: Deterrence}

In parallel to the aim of ending immunity the Court endeavours to provide a preventive function. ${ }^{73}$ This section shall review the crime prevention and drug control literature to provide an indication of whether the ICC could deter trafficking.

The primary objective of drug law enforcement is to increase risks, as increased risks translate into increased cost. As these costs are passed on to the consumer through inflated prices a barrier is erected which prevents would-be consumers, whilst compelling current consumers into treatment. The Courts objective would, therefore, be to increase the perceived risk of trafficking.

While much American, British and Canadian research into drug trafficking supports the deterrence effect of increased probability of arrest, studies tend to suggest that few traffickers perceive there to be much risk. ${ }^{74}$ If perceived risk is low in three of the worlds most developed and effective criminal justice systems then this does not bode well for

\footnotetext{
${ }^{72}$ See N. Grono, 2011, op. cit.

${ }^{73}$ R. Blattmann and K. Bowman, 2008, op. cit.

${ }^{74}$ S.H. Decker and M.T. Chapman, Drug Smugglings on Drug Smuggling: Lessons from the Inside (Philadelphia: Temple University Press, 2008); M. Layne, A. Bruen, P. Johnson, W. Rhodes, S. Decker, M. Townsend, C. Chester, G. Schaffer and J. Lavin, Measuring the Deterrent Effect of Enforcement Operations on Drug Smuggling, 1991-1999 (Office of National Drug Control Policy: NCJ 189988 PO 2869, 2001); see also F.J. Desroches, The Crime That Pays: Drug Trafficking and Organised Crime in Canada (Toronto, Canadian Scholars Press, 2005).
} 
Windle (2012) Afghanistan, Narcotics and the ICC. Pre-print copy.

Afghanistan. Nicholas Dorn and colleagues, for example, note how traffickers they interviewed:

... cited odds so small for their criminal conviction that they cannot be expressed meaningfully in quantitative terms. Some spoke of "like one in a hundred" (one person spoke of "one in four hundred"), but they made clear that what they meant by this was that it would be only "very bad luck" if such an organizer was convicted. The odds were simply too small to be expressed with any confidence. ${ }^{75}$

Traffickers interviewed in Canada similarly reported risks as 'moderate to low' ${ }^{76}$ Layne and colleagues asked traffickers incarcerated in America what would deter them. The findings suggest that a one in four chance of conviction would be sufficient risk to deter, whereas 94 percent would not be deterred by one in ten. Additionally none would be deterred by the prospect of a five year jail term, although all would be deterred by 25 years imprisonment. ${ }^{77}$

Rational choices are constrained by information on risks and rewards available to would be traffickers. Decisions also depend on the individuals interpretive skills, past experiences, and the time available. ${ }^{78}$ As such individuals may be deterred from trafficking if they perceive the risk as outweighing the rewards. ${ }^{79}$ Meaning the role of the criminal justice system must be to

\footnotetext{
${ }^{75}$ N. Dorn, L. Oette and S. White, 1998, 'Drugs Importation and the Bifurcation of Risk:

Capitalization, Cut Outs and Organized Crime', British Journal of Criminology, Vol. 38 No. 4: 537560 , p. 545.

${ }^{76}$ F.J. Desroaches, 2005 op. cit.

${ }^{77}$ M. Layne et al., 2001, op. cit.; also S.H. Decker and M.T. Chapman, 2008, op. cit.

${ }^{78}$ D.B. Cornish and R.V. Clarke, The Reasoning Criminal: Rational Choice Perspectives on Criminal Offending (New York: Springer Verlag, 1989); D.B. Cornish and R.V. Clarke, 'The Rational Choice Perspective,' in R. Wortley and L. Mazerolle (ed.) Environmental Criminology and Crime Analysis (London: Willan Publishing, 2008).

${ }^{79}$ M.A.R. Kleiman, When Brute Force Fails: How to Have Less Crime and Less Punishment (Oxford: Princeton University Press, 2009); P.H. Robinson and J.M. Darley, 2004, 'Does Criminal Law Deter? A Behavioural Science Investigation', Oxford Journal of Legal Studies, Vol. 24 No. 2: 173-205; M. Smith, R. Clarke and K. Pease, 'Anticipatory Benefits in Crime Prevention', in M. Smith and D.
} 
Windle (2012) Afghanistan, Narcotics and the ICC. Pre-print copy.

increase the perception of risk: ${ }^{80}$ make traffickers think there is a significant chance of punishment.

A study in Britain, however, found that half of incarcerated traffickers interviewed had underestimated their potential sentence. ${ }^{81}$ Similarly in America the majority of traffickers had expected to receive a sentence of 10 years, even though the federal sentencing guideline for high-level trafficking was 25 years. ${ }^{82}$ Another study found that while few traffickers incarcerated in America were aware that they could be arrested for 'dry' conspiracy (i.e. arrested without drugs in their possession) many retrospectively suggested that this would represent one of three major deterrents (the other two being the threat of informants and a prison term of 25 years or greater). ${ }^{83}$

As such if the Court and/or Afghan criminal justice system is to deter they must advertise potential sanctions, the chance of arrest must be perceived as high and sentence must be passed swiftly. ${ }^{84}$ This requires extensive intelligence. A starting point for intelligence will be the development of knowledge of trafficking structures, as this dictates not only the most appropriate strategy to employ but the potential effect of the removal of key figures.

\subsection{Effects: Trafficking structure}

Cornish (eds.) Theory for Practice in Situational Crime Prevention (Monsey, NY: Criminal Justice Press, 2003).

${ }^{80}$ D.M. Kennedy and S. Wong, The High Point Drug Market Intervention Strategy (U.S. Department of Justice, 2009); M.A.R. Kleiman, 2009, op. cit.

${ }^{81}$ Matrix Knowledge Group, 2007, The illicit drug trade in the UK (Consulted 19 May 2011) http://www.matrixknowledge.co.uk/the-illicit-drug-trade-in-the-united-kingdom/

${ }^{82}$ M. Layne et al., 2001, op. cit. p. 11; See S.H. Decker and M.T. Chapman, 2008, op. cit. An analysis of American street dealing has similarly suggested that the majority of dealers are unaware of increased certainty of arrest provided for by police operations. As such, police operations have minimal deterrence effect: D.M. Kennedy and S. Wong, 2009, op. cit.

${ }^{83}$ S.H. Decker and M.T. Chapman, 2008, op. cit.

${ }^{84}$ See M.A.R. Kleiman, 2009, op. cit. 
Windle (2012) Afghanistan, Narcotics and the ICC. Pre-print copy.

The organisational structure is the key. Effective policy and responses to drug smuggling require understanding the way smuggling is organised, or at least appreciating the diversity. ${ }^{85}$

There are two primary trafficking structures: network and hierarchal. Hierarchal structures are composed of 'clear departmental boundaries, clean lines of authority, detailed reporting mechanisms and formal decision making procedures'. ${ }^{86}$ Networks, on the other hand, are composed of interactions between multiple small independent groups or individuals, who pool resources for collective goals. ${ }^{87}$

There may be hierarchal groups operating within larger networks. In some networks a solid inner core subcontracts work to small cells. While the cells change, the core group is more permanent. ${ }^{88}$ Such networks have been referred to as 'wheel networks'. The so-called Columbian cocaine trafficking 'cartels', for example, were structured with a core group at the centre which exerted significant authority over independent sub-contracted cells. As the leaders of the two major networks were killed or imprisoned between 1989 and 1996 subcontracted cells started to branch out, developing more loosely linked and fluid network, described as 'chain networks'. ${ }^{89}$

Compartmentalisation of networks (i.e. many small groups insulated from others and the core) make it difficult for the police to infiltrate with intelligence and, trace and exploit linkages between cells. Network structures also limit the potential damage when law

\footnotetext{
${ }^{85}$ S.H. Decker and M.T. Chapman, 2008, op. cit., p. 158.

${ }^{86}$ W.W. Powell, 'Neither market nor hierarchy: Network forms of organization', in B.M. Staw and L.

L. Cummings (eds.) Research in Organizational Behaviour (Middlesex: JAI Press, 1990), p. 302.

${ }^{87} \mathrm{Ibid}$; M. Kenney, 2003, 'From Pablo to Osama: Counter-terrorism Lessons from the War on Drugs', Survival. Vol. 45, No. 3: 187-206; M. Kenney, From Pablo to Osama: Traffikcing and Terrorist Networks, Government Bureaucraies, and Comparative Adaptation (Pennsilvania: Penn State University Press, 2007).

${ }^{88}$ N. Dorn, M. Levi and L. King, Literature review on upper level drug trafficking (London: Home Office, 2005). For a discussion on how networks dominate the Canadian drugs market alongside a smaller number of hierarchal organisations see F.J. Desroches, 2005, op. cit.

${ }^{89}$ M. Kenney, 2007, op. cit.; see G. Bruisma and W. Bernasco, 2004, 'Criminal groups and Transnational Illegal Markets', Crime, Law and Social Change, Vol. 41: 79-94.
} 
Windle (2012) Afghanistan, Narcotics and the ICC. Pre-print copy.

enforcement penetrates their defences. If one cell is penetrated then the core can often call upon another cell to take its place. ${ }^{90}$ This does not suggest that the leaders of hierarchal organisation are not insulated: lower employees, including intermediaries and managers, often act as a buffer against law enforcement. ${ }^{91}$ The effect on hierarchal organisations may, however, be more significant and restructuring may be costlier. This said, any restructuring will incur costs. ${ }^{92}$

Research on the structure Afghan drugs market is scant. Felbab-Brown suggests that approximately 20 trafficking organisations operate within the country 'coalescing around important powerbrokers, both with and without links to the government' ${ }^{93}$ It appears that this small number of core groups sub-contract distribution to independent traffickers (including insurgent groups) and pay for the compliance of local power-holders (i.e. warlords, tribal leaders and state employees). ${ }^{94}$ This would suggest that Afghan opiate trafficking bear's closest resemblance to the wheel-network.

If Afghan trafficking organisations have wheel structures then the removal of high-ranking managers may have a significant effect. Following the experience of Columbia it is possible that there will be a short-term dip in production whilst the market adapts; possible by altering the structure closer to a chain-network. ${ }^{95}$ Conversely, if smaller organisations are targeted, then this may assist larger traffickers to increase their market share. As larger traffickers are often connected to warlords and insurgents, the result would likely be increased revenue for anti-government parties. $^{96}$ Therefore, the option with the least significant unintended

\footnotetext{
${ }^{90}$ H. Decker and M.T. Chapman, 2008, op. cit.; M. Kenney, 2007, op. cit.

${ }^{91}$ N. Dorn, L. Oette and S. White, 1998, op. cit.; M. Natarajan, 'Understanding the Structure of a Drug Trafficking Organisation: A Conversational Analysis', in M. Natarajan and M. Hough, eds., Crime Prevention Studies, Vol. 11: 273-298; Matrix Knowledge group, 2007, op. cit.

${ }^{92}$ J. Windle, J. and G. Farrell, 2012, 'Popping the Balloon Effect: Assessing Drug Law Enforcement in Terms of Displacement, Diffusion and the Containment Hypothesis', Substance Use and Misuse, Vol. 47, No. 8/9L 868-876.

${ }^{93}$ V. Felbab-Brown, 2009, op. cit., p. 29; also J.P. Caulkins, M.A.R. Kleiman, and J.D. Kulick, 2010, op. cit

${ }^{94}$ B.A. Rubin and J. Sherman, 2009, op. cit.; see M. Shaw, 2006, op. cit.

${ }^{95}$ See M. Kenney, 2003, op. cit.

${ }^{96}$ J.P. Caulkins, M.A.R. Kleiman, and J.D. Kulick, 2010, op. cit.
} 
Windle (2012) Afghanistan, Narcotics and the ICC. Pre-print copy.

consequences, and highest payoff in terms of increasing risk, might involve targeting major traffickers, especially those connected to anti-government actors.

Furthermore, Afghan traffickers may be categorised as what Nicholas Dorn and colleague's term 'politico-military': they aim to ensure 'a dominant position in existing political structures/states/failed states'. Interventions against such traffickers are often long-term processes involving the erosion of the organisations political, commercial or social support. Negotiations with competitors who pose less of a threat to the national security may be necessary. $^{97}$

In summary, law enforcement interventions in Afghanistan are significantly more complex, subtle and politically centred than building a case and arresting the bad guy. Such a strategy may even be counterproductive due to some traffickers' military and political power, geographical and political isolation, and the weakness of the Afghan criminal justice system. Rather, the state must work from the ground up by destroying the foundation upon which the trafficker's power is built upon.

\section{Should we negotiate?}

An issue raised by Barnet Ruben and Jake Sherman is whether to negotiate with traffickers. Many traffickers possess the entrepreneurial skills and knowledge of agricultural trading needed to advance the licit Afghan economy. For this reason, and to avoid increased conflict, negotiation may sometimes be more appropriate than arrest/prosecution. Negotiations, for example, may centre upon a covenant that traffickers receive immunity for past crimes if they invest in infrastructure, social welfare and/or legitimate business; whilst agreeing to cease their involvement in trafficking. It is envisaged that this would release resources to ensure the arrest of high-level traffickers connected to the insurgency: those who pose the greatest risk to Afghan security and stability. ${ }^{98}$

\footnotetext{
${ }^{97}$ N. Dorn, M. Levi and L. King, 2005, op. cit.

${ }^{98}$ B.A. Rubin and J. Sherman, 2009, op. cit.
} 
Windle (2012) Afghanistan, Narcotics and the ICC. Pre-print copy.

This option may be attractive. Many Afghan governors who may, or may not, be linked to the trade have expressed displeasure at the opium trade for conflicting with Islamic law. ${ }^{99}$ Others, who view themselves as business people, ${ }^{100}$ may see value in the legitimisation of their assets. If the Court can increase the perceived risk of trafficking then it may provide the Government with leverage to negotiate with traffickers to invest their capital, or for powerholders to break their links to the trade. The Court may, furthermore, represent an effective barrier to the potential corruption of the target selection process.

\section{Conclusion}

This article began by illustrating the weaknesses of the legal objections against prosecuting narcotics trafficking under the jurisdiction of the ICC. The article then used the case study of Afghanistan to investigate the potential effect that inclusion would have upon a country at the heart of the international illicit opiate trade.

It is suggested that there is potential for the Court to have a significant positive effect on Afghanistan in a number of ways. The strongest arguments are that inclusion would limit immunity from prosecution, make it more difficult to intimidate the judiciary, reduce the potential for escape after sentencing and provide much needed leverage in negotiations with traffickers. Better international cooperation may also make intelligence collection more effective. This may free the overstretched Afghan criminal justice system to concentrate on crimes of greater concern to the Afghan people.

Furthermore, many of the largest traffickers have residence, or hide their assets, outside of Afghanistan. ${ }^{101}$ For example, in 2009 between US\$1 and US\$2.5 billion is believed to have left the country for the Arab Emirates. ${ }^{102}$ An additional positive effect, not discussed so far,

\footnotetext{
${ }^{99}$ Ibid.

${ }^{100}$ See M. Shaw, 2006, op. cit.; Decker and Chapman found that many Columbian traffickers perceived themselves as 'businessmen' and dissociated themselves from the 'working-class work' of street selling: S.H. Decker and M.T. Chapman, 2008, op. cit., p. 208; also F.J. Desroaches, 2005, op. cit.

${ }^{101}$ B.A. Rubin and J. Sherman, 2009, op. cit.

${ }^{102}$ D. Filkins and M. Mazzetti, 2010, 'Key Zarzai Aide in Graft Inquiry is Linked to CIA,' New York Times, 26 August 2010.
} 
Windle (2012) Afghanistan, Narcotics and the ICC. Pre-print copy.

may be the utility of the Court in reducing the ability of traffickers to hide themselves or their money outside of Afghanistan.

The Court would need to be aware that the effect of its actions will depend on the structure of the Afghan drugs markets. Possessing a hierarchal or wheel-network structure means that a number of high-level arrests would likely significantly increase the price of Afghan opiates. The Court will then need to adapt its strategy in response to market reorganisation. Furthermore, the politico-military structure of Afghan trafficking means that the Court would likely have to play a political role in which the objectives of justice are put to one side during negotiations: the Court may have to accept that achieving a prosecution of one trafficker requires negotiation and compliance with another trafficker. It may also be that there are times when arresting and prosecuting a trafficker will not be in the long-term interest of state building, even if in the shorter-term interests of justice.

Negative effects might include traffickers being able to influence the Government to persuade the Court to target competitors and, the potential for ratification negotiations to escalate into violence and political opposition. Furthermore, as it is possible that negotiations may be more appropriate than law enforcement, the Courts prosecutors would be required to play a political role in which short-term law enforcement objectives are prioritised below long-term security and state building goals. Potentially conflicting with the law enforcement aims of the Court, especially the ending of immunity. (Even though institutional development, reduced conflict and state extension may be considered the most important long-term law enforcement objectives.)

The symbolism of the Court provides both a positive and negative, depending upon the perspective. It could be perceived as either an indication of the commitment of the state to the rule of law or a confession of the limitations of the Afghan criminal justice system.

In summary, the Court has the potential to either positively or negatively influence Afghanistan depending upon the discretion and priorities of the Courts prosecutors. This said, the primary objective in Afghanistan must be the formation of an effective criminal justice system. If foreign resources were displaced from the development of the Afghan criminal justice system into the ICC budget then it would become a burden; for there is greater utility in developing an effective Afghan criminal justice system than arresting a few major 
Windle (2012) Afghanistan, Narcotics and the ICC. Pre-print copy.

traffickers. If, however, the Court worked with the Afghan police and judiciary to improve their capabilities whilst freeing their resources for more traditional policing then the Court would likely be a great asset to the peoples of Afghanistan. 